\title{
Extra nucleolar activity associated with presence of a supernumerary chromosome segment in the grasshopper Oedipoda fuscocincta
}

\author{
J. P. M. Camacho, J. Navas-Castillo \\ and J. Cabrero
}

Departamento de Genética, Facultad de Ciencias, Universidad de Granada, 18071 Granada, Spain.

The standard males of Oedipoda fuscocincta show a single active nucleolus organiser region (NOR) located in the secondary constriction of the $\mathrm{M}_{9}$ chromosomes. Nine males from three different populations proved to be heterozygous for a heterochromatic supernumerary segment which is distally located on the $S_{10}$ chromosome. This also showed NOR activity. All available data seem to support the hypothesis that this extra segment on the $\mathbf{S}_{10}$ chromosome has arisen by translocation of part of the $M_{9}$ chromosome, specifically that located between the centromere and the secondary constriction.

\section{INTRODUCTION}

One form of chromosomal polymorphism commonly identified in acridid grasshoppers is that caused by the presence of extra chromatin segments attached one or more chromosomes of the standard complement. That is to say they are supernumerary chromosome segments. The majority of observed extra segments are heterochromatic in nature, although two cases of euchromatic ones have been recorded in the gomphocerine grasshoppers namely, Omocestus bolivari (Camacho et al., 1984) and Chorthippus binotatus (Cabrero, 1985). Those extra segments which are heterochromatic, as can be deduced from their heteropycnosis during first meiotic prophase, may show four types of response to $C$-banding (Camacho et al., 1984), which indicates their heterogeneous nature. A matter which has long caused controversy and still remains unresolved is the origin of supernumerary segments. White has $(1954 ; 1973)$ proposed two mechanisms by which extra segments may arise, firstly by translocation of chromosome material from the standard complement or else from a B chromosome, and secondly by duplication and heterochromatinisation of some part of the genome. The second hypothesis has been accepted by most authors (Shaw, 1970; 1971; John 1973; Hewitt, 1979; Camacho and Cabrero, 1982; Camacho et al., 1984) and indeed many arguments have been put forward against the translocation hypothesis (Hewitt, 1979).
However, in this paper we report a supernumerary chromosome segment containing an active NOR, which may serve as evidence in favour of the origin of this extra segment by means of translocation.

\section{MATERIALS AND METHODS}

Forty-seven adult males of the grasshopper Oedipoda fuscocincta Saussure were caught at five localities in the South of the Iberian Peninsula, specifically five males at Dornajo (Sierra Nevada, Granada), two males at Las Sabinas (Sierra Nevada, Granada), three males at Sierra de Pizarra (Málaga), two males at Sierra de Cázulas (Granada) and 35 males at Alcalá la Real (Jaén).

Testes were fixed in acetic ethanol $(1: 3)$ and subsequently were studied cytologically by the $\mathrm{C}$-banding technique described in Camacho et al. (1984) and the silver impregnation technique of Rufas et al. (1982).

\section{RESULTS AND DISCUSSION}

Like other species belonging to the subfamily Oedipodinae (Cabrero and Camacho, 1982; Camacho and Cabrero, 1983), Oedipoda fuscocincta has a chromosome complement consisting of $2 n=22+\mathrm{XO} / \mathrm{XX}$ telocentric chromosomes. The autosomes can be classified into three size 
groups: three long $\left(\mathrm{L}_{1}-\mathrm{L}_{3}\right)$, six medium $\left(\mathrm{M}_{4}-\mathrm{M}_{9}\right)$ and two short $\left(S_{10}\right.$ and $\left.S_{11}\right)$, the $X$ chromosome being the fourth element in size (Camacho, 1980). The $\mathrm{M}_{9}$ behaves like a megameric bivalent during first meiotic prophase, appearing positively heteropycnotic like the X chromosome (fig. 1(a)). The $\mathbf{M}_{9}$ bivalent possesses a secondary constriction near the centromere, just like that in $O$. coerulescens, $O$. charpentieri and species of the related genus Sphingonotus (Camacho, 1980). These secondary constrictions behave like "elastic constrictions" (White, 1957; John and Naylor, 1961; Mesa and de Mesa, 1967; John, 1976) in some cells at first meiotic prophase (fig. 1(b)-(d)).

In three out of the five populations sampled (Dornajo, Sierra de Cázulas and Alcalá la Real), we detected the presence of a heterochromatic extra segment distally located in the $S_{10}$ chromosome. This extra segment was carried by a total of nine heterozygous males, specifically two from

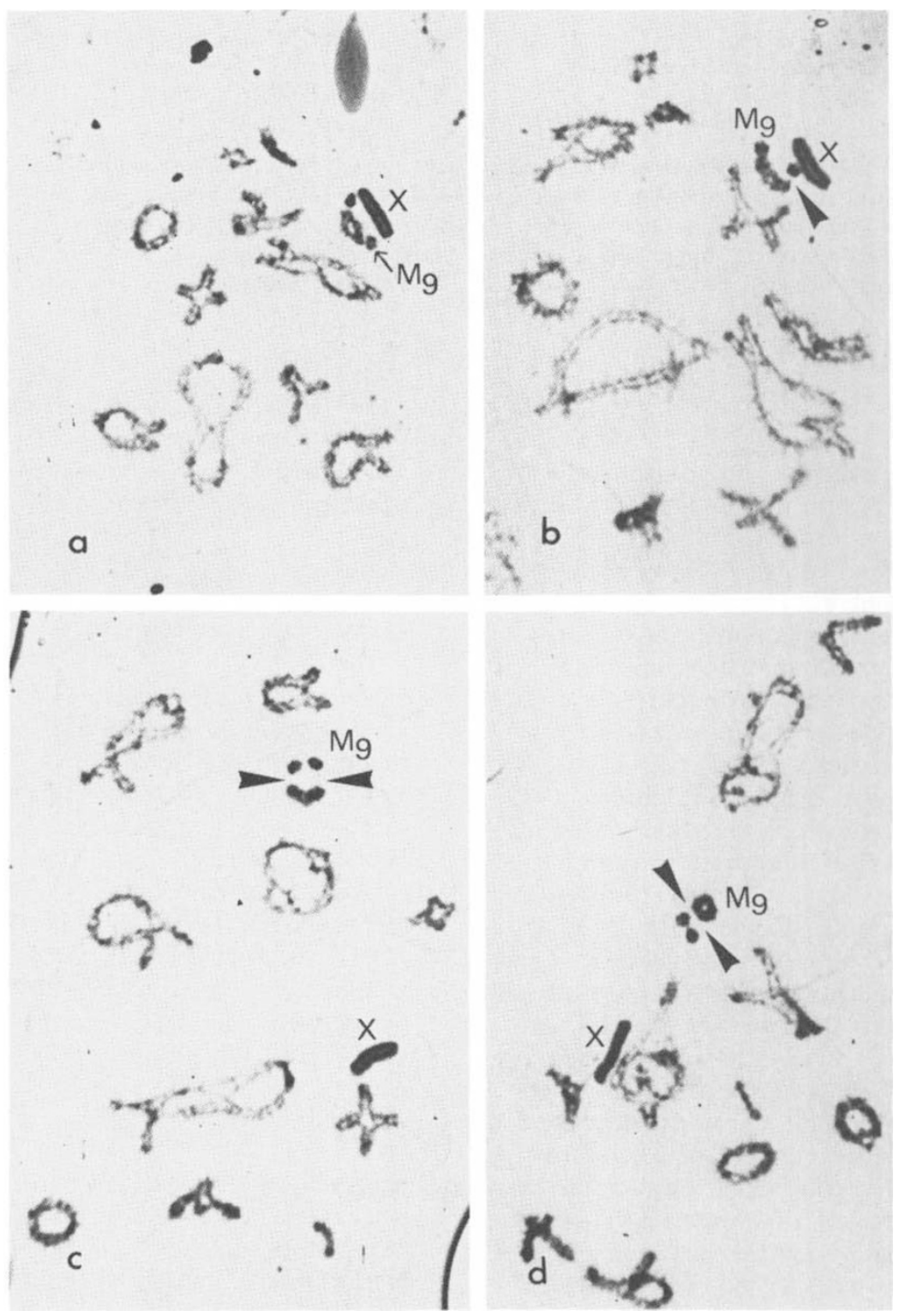

Figure 1 "Elastic constrictions" (arrows in (b)-(d)) in Oedipoda coerulescens, (a) Normal cell. (b) Cell showing the secondary constriction of one $\mathrm{M}_{9}$ chromosome behaving like an "elastic constriction". (c) and (d) Cells showing both secondary constrictions in the $\mathrm{M}_{9}$ bivalent behaving like "elastic constrictions". 
Dornajo, one from Sierra de Cázulas and six from Alcalá la Real. In previous papers we reported the existence of this supernumerary segment (Camacho and Cabrero, 1982) and its positive reaction to C-banding (Camacho et al., 1984) (see also fig. 2(a)). In the present investigation, we have analysed the activity of nucleolus organiser regions (NORs) in standard and $\mathrm{S}_{10}$-segmented males by means of the silver impregnation technique, which selectively stains the transcriptionally active NORs (Miller et al., 1976a,b). In grasshoppers, active NORs may only be demonstrated in the primary spermatocytes at pachytene and diplotene stages, in which a nucleolus appears joined to each active NOR so that bivalents carrying them are easily recognisable.

In standard males, the silver impregnation technique reveals the presence of a single nucleolus at zygotene and which in diplotene cells appears joined to the secondary constrictions of the $\mathrm{M}_{9}$ bivalent (fig. 2(b)). Hence, this species possesses a single active NOR located in the secondary constriction of the megameric bivalent. However, in males heterozygous for the supernumerary segment on the $\mathrm{S}_{10}$ chromosome, silver impregnation reveals the pesence of two nucleoli in zygoten

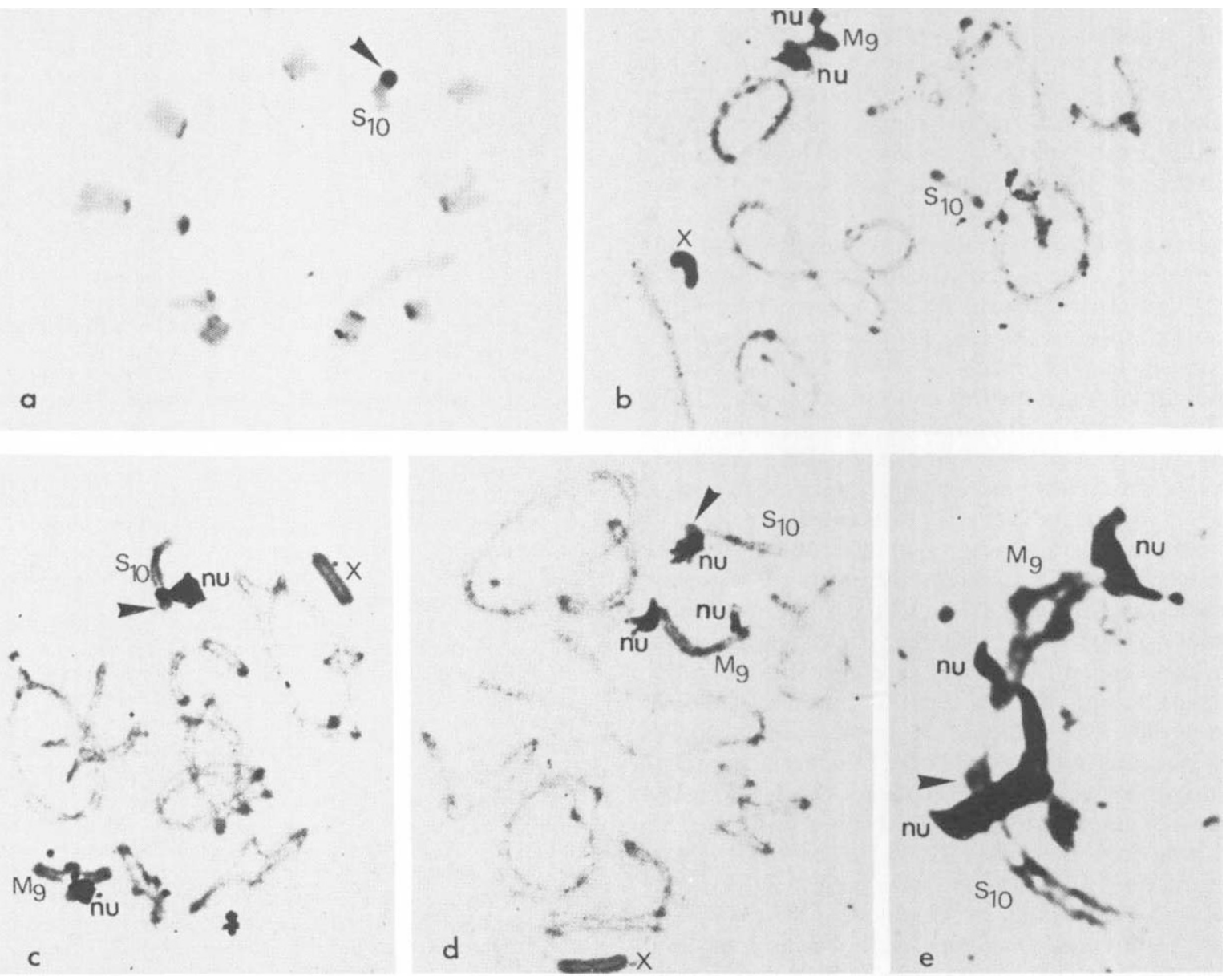

Figure 2 Nucleolar activity in Oedipoda fuscocincta. (a) Metaphase II showing the extra segment darkly C-banded (arrow). This cell is derived from a primary spermatocyte in which the $S_{10}$ heteromorphic bivalent divided equationally. (b) Silver stained diplotene cell from a standard male. Note the presence of nucleoli (nu) joined to the active NORs located in the secondary constrictions of the megameric $M_{9}$ bivalent, and the absence of nucleolar activity in the basic $S_{10}$ bivalent. (c) and (d) Silver stained cells from males heterozygous for the extra segment in the $S_{10}$ bivalent. Note nucleolar activity in the $M_{9}$ bivalent and also in the supernumerary segment of the $S_{10}$ bivalent. Arrows point to the extra segments, nu=nucleolus. (e) Silver stained partial diplotene cell showing NOR activity in the $M_{9}$ and the heteromorphic $S_{10}$ bivalent. Note the similar size of the extra segment (arrow) and the zone of $\mathrm{M}_{9}$ lying between centromere and the secondary constriction. Note the proximal location of the single chiasma in the hetromorphic $\mathrm{S}_{10}$ bivalents $(\mathrm{c})-(\mathrm{e})$ but the distal location in the basic ones (b). 
cells which in diplotene cells appear joined to the active NORs located in the secondary constrictions of the $\mathrm{M}_{9}$ bivalent and, additionally, in the zone by which the extra segment is joined to the $S_{10}$ chromosome (fig. 2(c)-(e)). This additional NOR in the extra segment of the $S_{10}$ was present in the nine heterozygous males analysed from three different populations. However, this extra nucleolar activity was never observed in the $S_{10}$ chromosomes lacking the supernumerary segment or in the $\mathrm{S}_{10}$ chromosomes of standard males. Thus it may be concluded that the extra NOR is contained in the supernumerary segment. The location of ribosomal RNA genes in supernumerary chromosome material has only been reported for the accessory chromosomes of several plant species: Crepis syriaca (Cameron, 1934), C. foetida vulgaris (Babcock, 1947), Alopecurus pratensis (Eosemark, 1957), Pennisetum typhoides (Powell and Burton, 1966), Gibasis linearis (Brandham and Bhattarai, 1977), Calycadenia (Carr and Carr, 1982), Allium flavum (Loidl, 1982) and $\boldsymbol{A}$. sphaerocephalon (Guillén and Ruiz Rejón, 1984). However, their presence in supernumerary chromosome segments has now been detected for the first time in the $\mathrm{S}_{10}$ chromosome of Oedipoda fuscocincta. The excess of NOR activity in those individuals carrying this extra segment may clearly be of adaptive significance because they have potentially increased their capacity for protein synthesis. This matter merits a more detailed investigation and will be carried out in future work.

An interesting factor may be deduced from our present investigation about the origin of this supernumerary segment. It could have been arisen by translocation of the segment of $\mathbf{M}_{9}$ chromosome lying between the centromere and the secondary constriction to a distal location in the $S_{10}$ chromosome. The size of this $\mathbf{M}_{9}$ segment is similar to that of the extra segment and, furthermore, both possess an active NOR. Indeed, the NOR in the extra segment can only be derived from the $\mathrm{M}_{9}$ chromosome because that is the only element of the standard karyotype possessing a NOR in the normal individuals of Oedipoda fuscocincta and also in those of $O$. coerulescens (Navas-Castillo et al., unpublished). It should also be noted that the secondary constrictions in the $\mathbf{M}_{9}$ bivalent of these two species behave so elastic that they may be points of easy breakage (Battaglia, 1964) thus facilitating chromosomal rearrangements.

Finally, if the above suggestion is correct the extra chromosome material must have become heterochromatinised in much the same way as additional autosomes have reported to become in polysomic males of grasshoppers (Hewitt and John, 1968; 1970; Fox et al., 1974; Camacho et al., 1981; Viseras and Camacho, 1984). However, it is clear that this heterochromatinisation has not affected the activity of the NOR in its new location in the $S_{10}$ chromosome.

Acknowledgements We would like to thank Ms Merce Romero for her aid in collecting the grasshoppers.

\section{REFERENCES}

BABCOCK, E. B. 1947. The genus Crepis, part two. Univ. Calif. Bot., 22.

BATTAGLiA, E. 1964. Un secondo caso de B-cromosomi $(2 n=$ $14+6-8 B$ ) in Scilla autumnalis L. (Liliaceae)proveniente dalla Palestina. Caryologia, 17, 65-76.

BOSEMARK, N. O. 1957. Further studies on accessory chromosomes in grasses. Hereditas, 43, 236-297.

BRANDHAM, D. E. AND BHATTARAI, C. 1977. The effect of B-chromosome number of chiasma frequency within and between individuals of Gibasis linearis (Commelinaceae). Chromosoma, 64, 343-348.

CABRERO, J. 1985. Estudios citogenéticos en saltamontes de la subfamilia Gomphocerinae: heterocromatina, reordenaciones cromosómicas y actividad nucleolar. Tesis doctoral, Universidad de Granada.

CABRERO, J. AND CAMACHO, J. P. M. 1982. Pericentric inversion polymorphism in Aiolopus strepens (Orthoptera: Acridadae): Effects on chiasma formation. Caryologia, 35, 411-424.

CAMACHO, J. P. M. 1980. Variabilidad cromosómica en poblaciones naturales de Tettigonioidea, Pamphagoidea y Acridoidea. Tesis doctoral. Universidad de Granada.

CAMACHO, J. P. M. AND CABRERO, J. 1982. Supernumerary segments in five species of grasshoppers (Orthoptera:Acridoidea). Genetica, 59, 113-117.

CAMACHO, J. P. M. AND CABRERO, J. 1983. Karyological differences between two species of grasshopper genus Acrotylus (Acrididae: Oedipodinae). Caryologia, 36, 121127.

CAMACHO, J. P. M., DIAZ DE LA GUARDIA, R. AND RUIZ REJON, M. 1981. Polysomy and supernumerary isochromosomes in the grasshopper Omocestus bolivari (Chopard). Heredity, 46, 123-126.

CAMACHO, J. P. M., VISERAS, E., NAVAS, J. AND CABRERO, J. 1984. C-heterochromatin content of supernumerary chromosome segments of grasshoppers: detection of an euchromatic extra segment. Heredity, 53, 167-175.

CAMERON, D. R. 1934. The chromosomes and relationships of Crepis syriaca (Bornm). Univ. Calif. Publ. Agr. Sci., 6, 357-386.

CARR, G. D. AND CARR, R. L. 1982. Micro and nucleolarorganizing B-chromosomes in Calycadenia (Asteraceae). Cytologia, 47, 79-87.

FOX, D. P., HEWITT, G. M. AND HALL, D. J. 1974. DNA replication and RNA transcription of euchromatic and heterochromatic regions during grasshopper meiosis. Chromosoma, 45, 43-62.

GUillen, A. AND RUIZ REJON, M. 1984. The B-chromosome system of Allium sphaerocephalon L. (Liliaceae): Types, effects and origin. Caryologia, 37, 259-267. 
HEWITT, G. M. 1979. Grasshoppers and crickets. Animal Cytogenetics, vol. 3: Insecta 1 Orthoptera, Gebrüder Borntraeger, Berlin-Stuttgard, $170 \mathrm{pp}$.

HEWITT, G. M. AND JOHN, B. 1968. Parallel polymorphism for supernumerary segments in Chorthippus parallelus (Zetterstedt) I. British populations. Chromosoma, 25, 319-342.

HEWITT, G. M. AND JOHN, B. 1970. Parallel polymorphism for supernumerary segments in Chorthippus parallelus (Zetterstedt) IV. Ashurst re-visited. Chromosoma, 31, 198-206.

JOHN, B. 1973. The cytogenetic systems of grasshoppers and locusts. II. The origin and evolution of supernumerary segments. Chromosoma, 44, 123-146.

JOHN, B. 1976. Myths and mechanisms of meiosis. Chromosoma, $54,295-325$.

JOHN, B. AND NAYLOR, B. 1961. Anomalous chromosome behaviour in the germ line of Schistocerca gregaria. Heredity, 16, 187-198.

LOIDL, J. 1982. B-chromosomes in Allium flavum (Liliaceae) and some related species. Plant Syst. Evol., 139, 197-207.

MESA, A. AND DE MESA, R. S. 1967. Complex sex-determining mechanisms in three species of South American grasshoppers (Orthoptera: Acridoidea). Chromosoma, 21, 163180.

MILLER, D. A., DEV, V. G., TANTRAVAHI, R. AND MILLER, O. J. 1976a. Suppression of human nucleolus organizer activity in mouse human somatic hybrid cells. Exptl. Cell Res., 101, 235-243.
Miller, O. J., Miller, D. A., DeV, V. G. AND CROCE, C. M 1976b. Expression of human and suppression of mouse nucleolus organizer activity in mouse human somatic cell hybrids. Proc. Natl. Acad. Sci. (Wash), 73, 4532-4533.

POWELL, J. B. AND BURTON, C. W. 1966. Nucleolar organizing accessory chromosomes in pearl millet. Crop. Sci., 6, 131134.

RUFAS, J. S., ITURRA, P., DE SOUZA, W. AND ESPONDA, P. 1982. Simple silver stainning procedure for the localization of nucleolus and nucleolar organizer under light and electron microscopy. Arch. Biol., 93, 267-274.

SHAW, D. D. 1970. The supernumerary segment system of Stethophyma. I. Structural basis. Chromosoma, 30, 326-343.

SHAW, D. D. 1971. The supernumerary segment system of Stethophyma. II. Heterochromatin polymorphism and chiasmata variation. Chromosoma, 34, 19-39.

VISERAS, E. AND CAMACHO, J. P. M. 1984. Polysomy in Omocestus bolivari: endophenotypic effects and suppression of nucleolar organizing region activity in the extra autosomes. Can. J. Genet. Cytol, 26, 547-556.

WhITE, M. J. D. 1954. Animal cytology and evolution. Cambridge Univ. Press, London, $454 \mathrm{pp}$.

WHITE, M. J. D. 1957. Cytogenetics of the grasshopper Moraba scurra. IV. Heterozygosity for "elastic constrictions". Aust. J. Zool., 5, 348-354.

WHITE, M. J. D. 1973. Animal Cytology and Evolution. Third Edition. Cambridge Univ. Press. 